\title{
Valorization of secondary feedstocks from the agroindustry by selective catalytic oxidation to formic and acetic acid using the OxFA process
}

\author{
Sebastian Ponce ${ }^{1} \cdot$ Stefanie Wesinger ${ }^{2} \cdot$ Daniela Ona $^{1} \cdot$ Daniela Almeida Streitwieser $^{1} \cdot$ Jakob Albert $^{2}$ (D)
}

Received: 3 April 2021 / Revised: 6 August 2021 / Accepted: 7 August 2021

(C) The Author(s) 2021, corrected publication 2021

\begin{abstract}
The selective oxidative conversion of seven representative fully characterized biomasses recovered as secondary feedstocks from the agroindustry is reported. The reaction system, known as the "OxFA process," involves a homogeneous polyoxometalate catalyst $\left(\mathrm{H}_{8} \mathrm{PV}_{5} \mathrm{Mo}_{7} \mathrm{O}_{40}\right)$, gaseous oxygen, p-toluene sulfonic acid, and water as solvent. It took place at 20 bar and $90{ }^{\circ} \mathrm{C}$ and transformed agro-industrial wastes, such as coffee husks, cocoa husks, palm rachis, fiber and nuts, sugarcane bagasse, and rice husks into biogenic formic acid, acetic acid, and $\mathrm{CO}_{2}$ as sole products. Even though all samples were transformed; remarkably, the reaction obtains up to 64, and 55\% combined yield of formic and acetic acid for coffee and cocoa husks as raw material within $24 \mathrm{~h}$, respectively. In addition to the role of the catalysts and additive for promoting the reaction, the influence of biomass components (hemicellulose, cellulose and lignin) into biogenic formic acid formation has been also demonstrated. Thus, these results are of major interest for the application of novel oxidation techniques under real recovered biomass for producing value-added products.
\end{abstract}

Keywords Secondary feedstock $\cdot$ Agricultural waste $\cdot$ Biomass oxidation $\cdot$ Polyoxometalates $\cdot$ OxFA process $\cdot$ Residual biomass

\section{Introduction}

Biomass plays a key role towards a future green economy for the production of renewables, heat, biofuels, pharmaceuticals, and green chemical feedstocks [1-3]. However, bioenergy at industrial production might trigger possible water privation, can limit land availability, and certainly, will increase the food prices [4-9]. Second generation feedstocks, which include biomass residues from the agroindustry, appear as a stop-arguing-solution. Though, most of them remain untreated and underutilized. For instance,

Jakob Albert

jakob.albert@chemie.uni-hamburg.de

1 Department of Chemical Engineering, Institute for Development of Alternative Energies and Materials IDEMA, Universidad San Francisco de Quito USFQ, Diego de Robles S/N Y Av. Interoceánica, Quito, EC 170157, Ecuador

2 Institut Für Technische Und Makromolekulare Chemie, Universität Hamburg, Bundesstraße 45, 20146 Hamburg, Germany in emerging nations, which usually generate big amounts of biomass, half of them end up in open-air dumps or unplanned landfills $[10,11]$. Therefore, implementation of novel alternatives of biomass valorization is highly desirable.

Many emerging countries with a traditionally agricultural based-economy have a great potential for recovering and converting biomass residues into energy and more valuable green chemicals. Being palm heart, sugarcane, cocoa, palm oil, rice, maize, banana, and pineapple crop the most representative $[12,13]$. Huge efforts have been made in order to show its potential applying common biomass conversion processes in the last years. Producing pyrolysis gas, biooil, and solid biochar via thermochemical methods (e.g., fast-pyrolysis and combustion) has been studied [14-16]. Biochemical processes, like anaerobic digestion, have been also applied for biogas generation [17, 18]. Moreover, alcoholic fermentation and submerged fermentation techniques have been studied for bioethanol and organic acid production, respectively [19]. Nevertheless, the use of alternative ways to convert agricultural biomass into products with more value-added applications (e.g., formic acid (FA), acetic 
acid (AA)) is still an unchartered territory. Formic acid, for example, has found applications in many industries, which include textile, agriculture, and pharma, among others. Lately, it has been also studied as energy carrier and ideal fuel for fuel cells [20, 21]. In this sense, Albert et al. have shown the possibility of transforming biomass into green fuels and chemical via bio-FA decomposition to syngas $\left(\mathrm{H}_{2}\right.$ and CO), and subsequently, Fisher-Tropsch synthesis [22], showing its importance as a future energy vector.

In this context, one attractive approach for valorization of organic residues is the transformation of lignocellulosic biomass into formic acid and acetic acid via metal catalysts (see Fig. 1a and b) [23-28], the so-called OxFA process [29]. The OxFA process runs under moderate temperature conditions $(<373 \mathrm{~K})$ with oxidants such as air or oxygen. In the last years, a number of water-soluble and non-soluble substrates have been successfully converted (glucose, cellobiose, sucrose, beech, wood, among many others) $[23,26]$. Polyoxometalates (POMs) are the chosen catalysts for this type of homogeneous catalytic reaction. Advantageous are their strong Brönsted acidity and stability in aqueous solution. In particular, POMs from the Keggintype $\left[\mathrm{H}_{3+\mathrm{n}} \mathrm{PV}_{\mathrm{n}} \mathrm{Mo}_{12} \mathrm{O}_{40}\right]$ (also known as HPA-n) with different amounts of vanadium-substitution have been the most studied catalysts. High amounts of vanadium substitution in the catalysts have widely proven that both the reduction and reoxidation steps (see redox cycle in Fig. 1b) become faster. Being HPA-5 the fastest and with highest selectivity towards FA formation [30, 31], due to active $\mathrm{VO}_{2}^{+}$species dissolved in the reaction media. Concerning water-insoluble biomass, p-toluenesulfonic acid (TSA) showed to be an efficient additive as hydrolyzing and phase transfer agent promoting higher amounts of FA [29]. In addition to the selection of the right catalysts and assuring a fully homogenized reaction media, the biomass composition has shown to play a major role during the reaction. Previous studies have shown that POMs catalyze first the decomposition of hemicellulose, then oxidize the phenolic lignin. Thus, different biomass residues would find distinct alternative valorization pathways [27].
Herein, a complete screening for the oxidative conversion applying the OxFA process under seven representative fully characterized biomasses recovered the agroindustry is presented. In this first approach, the standard method of the OxFA process presented in Preuster and Albert [29] was applied using a HPA-5 polyoxometalate $\left(\mathrm{H}_{8} \mathrm{PV}_{5} \mathrm{Mo}_{7} \mathrm{O}_{40}\right)$ catalyst at 20 bar and $90{ }^{\circ} \mathrm{C}$ in aqueous solution. The yield and selectivity of the products are analyzed as function of the biomass composition. These results are of major interest for all geographies and countries with similar agro-industrial sectors and biomass composition, in order to valorize residues and producing value-added products for upcoming needs.

\section{Materials and methods}

\subsection{Materials}

Glacial acetic acid (100\%, Fischer Scientific ACS Plus), nitric acid (69\%, Loba Chemie), hydrochloric acid (37\%), sodium hydroxide (40\%, Fischer Scientific), sulfuric acid (97\%, Fischer Scientific), and hexane (98.5\%, Fischer Scientific) were used as chemicals for ash, cellulose, lignin, fats, and proteins content analysis.

All chemicals were purchase and used as received without additional purification.

\subsection{Catalyst synthesis and characterization}

According to literature [25, 32], the heteropolyacid catalyst $\left(\mathrm{H}_{8}\left[\mathrm{PV}_{5} \mathrm{Mo}_{7} \mathrm{O}_{40}\right]\right)(\mathrm{HPA}-5)$ was synthesized. A P:V:Mo (1:5:7) ratio by a ICP-OES (Perkin-Elmer, Plasma 400) analysis was obtained. As depicted in Fig. S1 in Supporting Information (SI), the infrared spectra showed a characteristic stretching vibration for the kegging-oxoanion. Spectra was recorded in FT-IR spectrophotometer (Shimadzu, Prestige-21) in combination with a Golden Gate single reflection diamond ATR crystal in the range of 4000 to $400 \mathrm{~cm}^{-1}$. As shown in Fig. S2 in SI, a two-step loss of water typical for
Fig. 1 Schematic of the heteropolyacid catalyst (HPA-n) redox cycle in the OxFA process. Biomass partial oxidation to products (a) and catalysts reduction and oxidation steps (b)

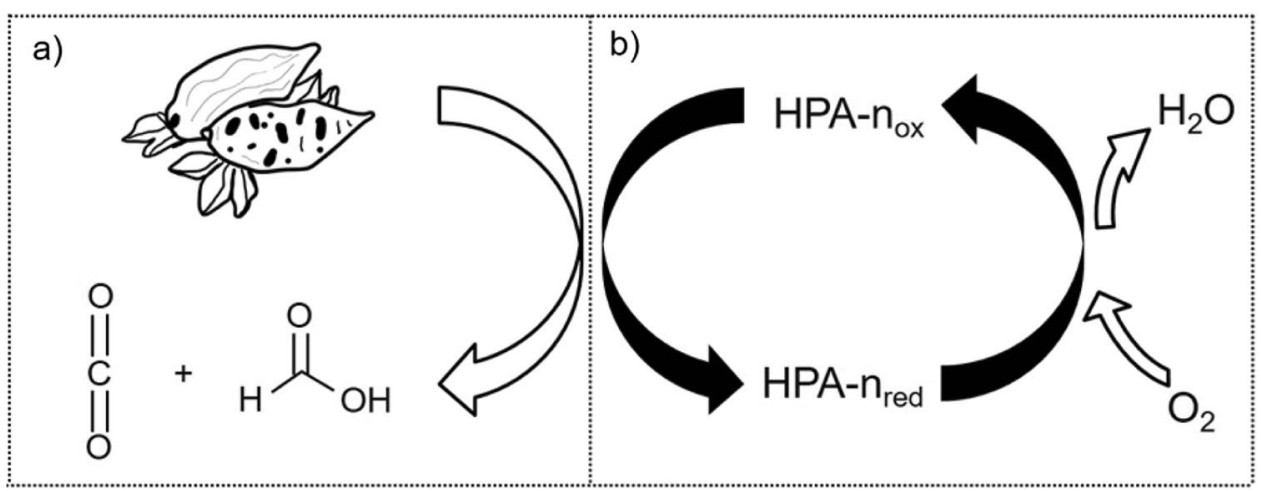


heteropolyacids of the Keggin type was identified. Eleven and $5 \mathrm{wt} \%$ loss of crystallization and constitutional water, respectively, led to in $14 \mathrm{~mol}$ of hydrated $\mathrm{H}_{2} \mathrm{O}$ per mole of heteropolyacid catalyst. Moreover, a catalyst molar mass of $1857 \mathrm{~g} \mathrm{~mol}^{-1}$ was calculated. Samples were tested in a thermogravimetric analyzer (SETARAM Instruments, SETSYS-1750 CS Evolution).

\subsection{Biomass selection and characterization}

Seven different residual biomasses were selected (please refer to table S1 in SI) and characterized as follows. All biomasses were dried, cut, grounded, and sieved (sieve opening: $250 \mu \mathrm{m}$ ). One and $2 \mathrm{~g}$ of dried biomass were used for the determination of fats and proteins content, and percentage of ash, lignin, and cellulose, respectively.

Ash content was determined applying the AOAC 942.5 standard gravimetric method [33]. Biomass fat content was analyzed by a modified version of the Randall method according to the official standards AOAC 2003.05 and AOAC 2003.06 [34] with solvent extractor equipment VELP Scientifica SER 148.

The amount of protein was quantified as nitrogen content based on the Kjeldahl method and the official method AOAC 960.52 [33] in a digester DK6 VELP Scientifica and a semiautomatic distillation equipment UDK 139. This method allowed obtaining the amount of nitrogen by the titration volume and then calculating the percentage of proteins using a nitrogen to protein conversion factor of 6.25 for all biomasses except rice husks that has a protein conversion factor of 5.95 according to the table of specific factors of food protein content [35]. Total carbohydrates content was obtained mathematically by subtracting the results of fat, protein, and ash from the total dry sample weight. Cellulose content was determined using the protocol described by KürschnerHanack using acetic and nitric acid [36]. The lignin content was obtained applying the AOAC 973.18 method [33], and hemi-cellulose was calculated by subtracting cellulose and lignin from the total carbohydrate content (see Table 1 and Table S2 in SI). Finally, the morphology and the surface of biomass samples were analyzed in a scanning electron microscope JEOL JSM-IT300LA (15 kV, $50 \mathrm{~Pa})$. Images of raw biomasses can be seen in Fig. S3 in SI.

For molar calculations, elemental analysis was conducted to measure $\mathrm{C}, \mathrm{H}, \mathrm{N}, \mathrm{S}$, and $\mathrm{O}$ contents in the recovered biomass. The Flash 2000 Thermo Scientific elemental analyzer was operated with constant helium and/or oxygen flow (250 and $300 \mathrm{~mL} \mathrm{~min}{ }^{-1}$, respectively) at $950{ }^{\circ} \mathrm{C}$. For each measurement, approximately $2 \mathrm{mg}$ of biomass sample were used (see Table S3 in SI).

\subsection{Biomass oxidation reactions}

A 600-mL high pressure reactor (Hastelloy, C276) equipped with a gas entrainment impeller was used. For working with oxygen in a safe environment, all fittings, valves, and pipes were made of stainless Steel-Austenitic-1.4571. No leakage was ensured with a PTFE sealing. A safety released valve adjusted to 100 bar was also installed.

For each oxidation reaction, $40 \mathrm{mmol}$ of biomass and $0.4 \mathrm{mmol}$ of HPA-5 catalyst (substrate to catalyst ratio $=100: 1)$ as well as $4 \mathrm{mmol}$ of the additive p-toluenesulfonic acid (substrate to additive ratio $=10: 1$ ) were added to the reaction system. Then, $100 \mathrm{~mL}$ of water were added. Resulting in a turnover number of the catalysts of 100 which lies within an acceptable value for batch processes at laboratory scale. The autoclave was purged at least three times with oxygen. The heating was started on and the stirrer speed set to $300 \mathrm{rpm}$. Soon after the reactor reached the set temperature $\left(90^{\circ} \mathrm{C}\right)$, the oxygen pressure was adjusted to $20 \mathrm{bar}$. Then, the stirrer speed was increased to $1000 \mathrm{rpm}$. These conditions were kept for $24 \mathrm{~h}$, while pressure and temperature were constantly monitored.

\subsection{Product analysis}

After the reaction took place, the system was cooled down. Gaseous products were collected in gas bags and its composition were analyzed by a gas chromatograph (Varian 450-GC (TCD/FID)) equipped with a Shin Carbon ST column $(2 \mathrm{~m} \times 0.75 \mathrm{~mm}$ ID) was used. Moreover, liquid-phase products were analyzed with a HPLC (Jasco
Table 1 Carbohydrate, cellulose, lignin, and hemicellulose content from the seven residual biomasses from the agro-industry

\begin{tabular}{lllllr}
\hline Sample & Biomass residue & $\begin{array}{l}\text { Carbohydrate } \\
\mathbf{( \% )}\end{array}$ & $\begin{array}{l}\text { Cellulose } \\
\mathbf{( \% )}\end{array}$ & $\begin{array}{l}\text { Lignin } \\
\mathbf{( \% )}\end{array}$ & \multicolumn{1}{l}{$\begin{array}{l}\text { Hemicellulose } \\
\mathbf{( \% )}\end{array}$} \\
\hline 1 & Coffee husks & $78.22 \pm 0.29$ & $40.40 \pm 2.70$ & $34.00 \pm 0.56$ & $3.82 \pm 2.52$ \\
2 & Cocoa husks & $82.13 \pm 0.14$ & $37.91 \pm 1.01$ & $31.67 \pm 0.29$ & $12.56 \pm 0.95$ \\
3 & Palm rachis & $85.55 \pm 1.31$ & $33.29 \pm 1.27$ & $16.15 \pm 0.31$ & $36.12 \pm 1.00$ \\
4 & Palm fiber & $72.05 \pm 2.61$ & $23.51 \pm 0.61$ & $28.83 \pm 0.86$ & $19.71 \pm 3.47$ \\
6 & Palm nut & $90.60 \pm 0.44$ & $20.07 \pm 0.57$ & $43.27 \pm 1.11$ & $27.27 \pm 1.51$ \\
6 & Sugarcane bagasse & $95.90 \pm 0.43$ & $18.08 \pm 0.11$ & $19.57 \pm 0.48$ & $58.25 \pm 0.48$ \\
7 & Rice husks & $76.88 \pm 0.21$ & $35.50 \pm 0.77$ & $18.17 \pm 0.44$ & $23.21 \pm 0.45$ \\
\hline
\end{tabular}


Instrument) equipped with a Shodex SUGAR SH1011 column $(300 \mathrm{~mm} \times 8 \mathrm{~mm})$. Prior to injection, the sample was filtered with a one-time Micropur PET filter (Altmann Analytik) with a pore width of $0.2 \mu \mathrm{m}$ to remove the remaining catalysts. The liquid additive toluene sulfonic acid was not removed from the mixture prior to analysis. Though for scale up processes, its separation has been studied in previous studies [37]. A Jasco HPLC with Shodex SH1011 separation column $(300 \mathrm{~mm} \times 8 \mathrm{~mm}$ ) was used to analyze the liquid samples. The outer material of the column is SUS-316 steel, and the column material is styrene, divinylbenzene, and copolymer. The samples were injected through a $45-\mu \mathrm{m}$ syringe filter into a GC vial for preparation. For measurement, $10 \mu \mathrm{l}$ of sample is injected and measured at a flow rate of $1 \mathrm{ml} / \mathrm{min}$ for $45 \mathrm{~min}$. The eluent is $0.005 \mathrm{M}$ sulfuric acid. The temperature of the column is kept constant at $50{ }^{\circ} \mathrm{C}$ using an oven (Jeatstram 2-Plus from Jasco). As detector served a RI detector (200 series) from Perkin Elmer.

\subsection{Determination of yield and selectivity}

The yields and selectivity of the gaseous and liquid products (FA, AA, $\mathrm{CO}_{2}$, and $\mathrm{CO}$ ) were calculated by Eq. (1).

$Y_{i}=\frac{n_{\text {product }, i}}{n_{\mathrm{c}-\text { atoms,substrate }}}$

where $Y_{\mathrm{i}}$ is the molar carbon yield of each product (determined either by HPLC (liquid phase) or GC (gas phase), $n_{\text {Product }, I}$ is the molar carbon amount of each product, and $n_{\text {C-Atoms substrate }}$ is the molar amount of carbon initially present in each substrate determined by CHNS analysis.

The total carbon yield (TOC) was calculated by Eq. (2). This value was used to represent biomass conversion, as no other products were detected via the analytical methods.

$\mathrm{TOC}=\frac{\sum_{i} n_{\text {product }, i}}{n_{\mathrm{c}-\text { atoms,substrate }}}$

The selectivity of the products was calculated by the product yield divided by the TOC.

\section{Results and discussion}

The study shows the potential of residual biomass as a secondary feedstock for oxidative conversion into more valuable chemicals, such as formic acid and acetic acid, but also carbon dioxide formation. For this purpose, seven representative biomass residues from the agroindustry were selected, namely, coffee, cocoa and rice husks, sugarcane bagasse, and waste from a palm oil factory (e.g., palm fiber, palm rachis, and palm nuts) (see source and location of biomasses in Table S1 in SI). For understanding the efficiency of the oxidative reaction system, the seven substrates were fully characterized. Their cellulose, lignin, and hemicellulose composition were determined, as described in the experimental section and can be seen in Table 1 and Figure S4 in the supplementary Information. Moreover, the elemental analysis of each substrate allows the calculation of yields based on the carbon atoms present in the biomass (see results in Table S3 in SI). With these results, the molecular composition of each biomass was obtained.

All biomasses were processed with a Keggin-type polyoxometalate catalyst (HPA-5, $\left.\left[\mathrm{H}_{8} \mathrm{PV}_{5} \mathrm{Mo}_{7} \mathrm{O}_{40}\right]\right)$, TSA as an additive, and water as a solvent for $24 \mathrm{~h}$, at 20 bar oxygen pressure, and $90{ }^{\circ} \mathrm{C}$. For HPA- 5 catalyzed redox processes, it has been widely demonstrated that moderate oxygen pressure (20 bar) guarantees the substrate oxidation to be ratedetermining, as the reoxidation of higher substituted HPAs is favored by higher amounts of vanadium in the Keggin structure [25]. At $90{ }^{\circ} \mathrm{C}$, the HPA-5 catalyst shows a maximum of activity, while temperatures over $100^{\circ} \mathrm{C}$ are not favorable due to possible product decomposition. In addition, in a former publication [27], TSA showed to act as the most efficient solubility promoter for water-insoluble biomass. As already mentioned, p-toluenesulfonic acid speeds the biomass conversion up without being consumed or transformed during the reaction. The results of the recovered agro-industrial biomass experiments applying the above described parameters are shown in Tables 2 and 3, respectively.

The results in Table 2 clearly show that the used homogeneously catalyzed oxidation system is able to convert all applied biomasses like coffee husks (97\% combined yield), cocoa husks (100\% combined yield), palm rachis, fibers and nuts (92, 88, and $71 \%$ combined yield, respectively), sugarcane bagasse (79\% combined yield), and rice husks (53\% combined yield) into formic acid, acetic acid, and carbon dioxide. Under the reaction conditions, formation of carbon monoxide ( $\approx<1.5 \% \mathrm{CO}$ yield) due to FA decomposition can be neglected. These results were expected as the HPA-5 catalyst has proven to convert all three components of lignocellulosic biomass (cellulose, lignin, and hemicellulose) under the applied reaction conditions. However, HPA-5 catalyst performance towards FA production would differ depending on the representative group (in order of activity: cellulose $\approx$ hemicellulose $\gg$ lignin) [27]. Thus, yield to FA and AA strongly depends on the substrate structure and the number of oxygen-functionalities in the carbon-network.

Remarkably, between the seven fully characterized substrates, the best recovered biomass for converting into formic acid and acetic acid was found to be coffee husks with $64 \%$ FA + AA-combined yield (sample 1), followed by cocoa husks 55\% FA + AA-combined yield (Sample 2), and palm rachis and sugarcane bagasse with $\approx 50 \% \mathrm{FA}+\mathrm{AA}$-combined yield (Samples 3 and 6, respectively). Interestingly, for future applications, in all biomasses, selectivity towards 
Table 2 Screening of seven different biomasses recovered from the agro-industry using a HPA-5 catalyst in batch mode

\begin{tabular}{|c|c|c|c|c|c|c|c|}
\hline Sample $^{\mathrm{a}}$ & Substrate & Molecular composition $^{\mathrm{b}}$ & $\begin{array}{l}\text { FA-yield } \\
(\%)\end{array}$ & $\begin{array}{l}\text { AA-yield } \\
\text { (\%) }\end{array}$ & $\begin{array}{l}\mathrm{CO}_{2} \text {-yield } \\
(\%)\end{array}$ & $\begin{array}{l}\text { CO-yield } \\
\%(\end{array}$ & $\begin{array}{l}\text { Total } \\
\text { carbon } \\
\text { yield } \\
(\%)\end{array}$ \\
\hline 1 & Coffee husks & $\mathrm{C}_{1.53} \mathrm{H}_{2.21} \mathrm{O}_{1}$ & 42.0 & 22.2 & 31.0 & 1.2 & 97 \\
\hline 2 & Cocoa husks & $\mathrm{C}_{2.01} \mathrm{H}_{2.61} \mathrm{O}_{1}$ & 37.6 & 18.1 & 46.4 & 1.6 & 100 \\
\hline 3 & Palm rachis & $\mathrm{C}_{1.31} \mathrm{H}_{2.06} \mathrm{O}_{1}$ & 31.4 & 18.3 & 40.1 & 1.5 & 92 \\
\hline 4 & Palm fiber & $\mathrm{C}_{1.37} \mathrm{H}_{1.92} \mathrm{O}_{1}$ & 27.2 & 14.4 & 45.3 & 1.6 & 88 \\
\hline 5 & Palm nut & $\mathrm{C}_{2.08} \mathrm{H}_{2.58} \mathrm{O}_{1}$ & 18.8 & 13.0 & 37.3 & 1.5 & 71 \\
\hline 6 & Sugarcane bagasse & $\mathrm{C}_{1.59} \mathrm{H}_{2.20} \mathrm{O}_{1}$ & 38.3 & 12.8 & 27.4 & 0.8 & 79 \\
\hline 7 & Rice husks & $\mathrm{C}_{2.31} \mathrm{H}_{3.94} \mathrm{O}_{1}$ & 19.0 & 9.0 & 24.1 & 0.9 & 53 \\
\hline
\end{tabular}

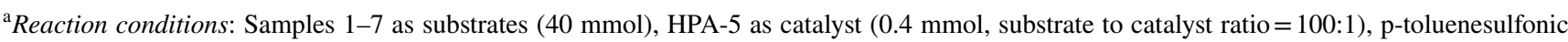
acid as additive $(4 \mathrm{mmol}$, substrate to additive ratio $=10: 1)$, water as solvent $\left(100 \mathrm{~g} \mathrm{H}_{2} \mathrm{O}\right), 90{ }^{\circ} \mathrm{C}, 20$ bar $\mathrm{O}_{2}$ (Fed-Batch mode), $1000 \mathrm{rpm}$ stirrer speed. 24-h reaction time

${ }^{\mathrm{b}}$ Determined via $\mathrm{C}, \mathrm{H}, \mathrm{N}$, and S elemental analysis

Table 3 Organic acid selectivity from processing different recovered biomass feedstocks

\begin{tabular}{lllll}
\hline Sample $^{\mathrm{a}}$ & Substrate & Molecular composition $^{\mathrm{b}}$ & $\begin{array}{l}\text { FA-selectivity } \\
(\boldsymbol{\%})\end{array}$ & $\begin{array}{l}\text { AA-selectivity } \\
(\boldsymbol{\%})\end{array}$ \\
\hline 1 & Coffee husks & $\mathrm{C}_{1.53} \mathrm{H}_{2.21} \mathrm{O}_{1}$ & 43.4 & 22.9 \\
2 & Cocoa husks & $\mathrm{C}_{2.01} \mathrm{H}_{2.61} \mathrm{O}_{1}$ & 36.2 & 17.4 \\
3 & Palm rachis & $\mathrm{C}_{1.31} \mathrm{H}_{2.06} \mathrm{O}_{1}$ & 34.2 & 19.9 \\
4 & Palm fiber & $\mathrm{C}_{1.37} \mathrm{H}_{1.92} \mathrm{O}_{1}$ & 30.8 & 16.2 \\
5 & Palm nut & $\mathrm{C}_{2.08} \mathrm{H}_{2.58} \mathrm{O}_{1}$ & 26.6 & 18.5 \\
6 & Sugarcane bagasse & $\mathrm{C}_{1.59} \mathrm{H}_{2.20} \mathrm{O}_{1}$ & 48.3 & 16.2 \\
7 & Rice husks & $\mathrm{C}_{2.31} \mathrm{H}_{3.94} \mathrm{O}_{1}$ & 35.9 & 17.1 \\
\hline
\end{tabular}

$M B$ mass balance

${ }^{a}$ Reaction conditions: Samples $1-7$ as substrates $(40 \mathrm{mmol}), \mathrm{HPA}-5$ as catalyst $(0.4 \mathrm{mmol}$, substrate to catalyst ratio $=100: 1)$, p-toluenesulfonic acid as additive $(4 \mathrm{mmol}$, substrate to additive ratio $=10: 1)$, water as solvent $\left(100 \mathrm{~g} \mathrm{H}_{2} \mathrm{O}\right), 90{ }^{\circ} \mathrm{C}, 20$ bar $\mathrm{O}_{2}$ (Fed-Batch mode), $1000 \mathrm{rpm}$ stirrer speed. 24-h reaction time

${ }^{\mathrm{b}}$ Determined via $\mathrm{C}, \mathrm{H}, \mathrm{N}$, and $\mathrm{S}$ elemental analysis
FA is favorable, being almost twice as high as for AA (see Table 3). These values, as much as the authors know, are the highest obtained by the oxidative conversion of residual biomass. Note that all these latter four represent a high percentage of the total residual biomass produced in developing countries, making this technology an interesting opportunity for supporting the food and agro-industry.

Superior coffee and cocoa husk conversion into FA and AA can be correlated to their high amount of cellulose in the structure $(\approx 40 \%$, see example for coffee husks in Fig. 2a). On the other hand, the huge content of hemicellulose is responsible for positive, but lower results, on palm rachis and sugarcane bagasse wastes $(\approx 58 \%$, see example for sugarcane bagasse Fig. 2b). Finally, as mentioned above, the HPA-5 catalyst is less able to convert lignin during the oxidative process; therefore, lower conversions using palm nuts and palm fibers can be explained. If we compare them, as show in Table 2, a major production of $\mathrm{CO}$ and $\mathrm{CO}_{2}$ in substrates with higher lignin content is observable. Thus, certainly, most lignin is transformed into $\mathrm{CO}$ and $\mathrm{CO}_{2}$ (see example for palm nut in Fig. 2c; for other biomass compositions, please refer to Fig. S4 in SI). These results, are in accordance with former studies developed under biogenic substrates [26]. For rice husks, a proper correlation between its poor conversion (53\%) and biomass composition could not be found. However, after reaction, a solid leftover, containing mainly ashes, was observed. This is in accordance with the high ash content $(\approx 20 \%)$ compared to other biomasses $(\approx<5 \%)$ found in rice husks after characterization (see values in Table $\mathrm{S} 2$ in $\mathrm{SI}$ ). It is well known that ashes contain a number of alkali and alkaline metals like $\mathrm{Ca}, \mathrm{Na}$, $\mathrm{K}$, and $\mathrm{Mg}$, but also $\mathrm{Si}$ and $\mathrm{P}$, and transition metals such as $\mathrm{Fe}, \mathrm{Al}$, and $\mathrm{Mn}$, which can affect positively or negatively the reaction $[38,39]$. Herewith, the high ash content has a negative effect on the conversion of the substrate (see Table 2, the higher the ash content, the lower is the conversion resp. total 
Fig. 2 Components of residual biomass recovered from the agro-industry. a Coffee husks, b sugarcane bagasse, and $\mathbf{c}$ palm nut
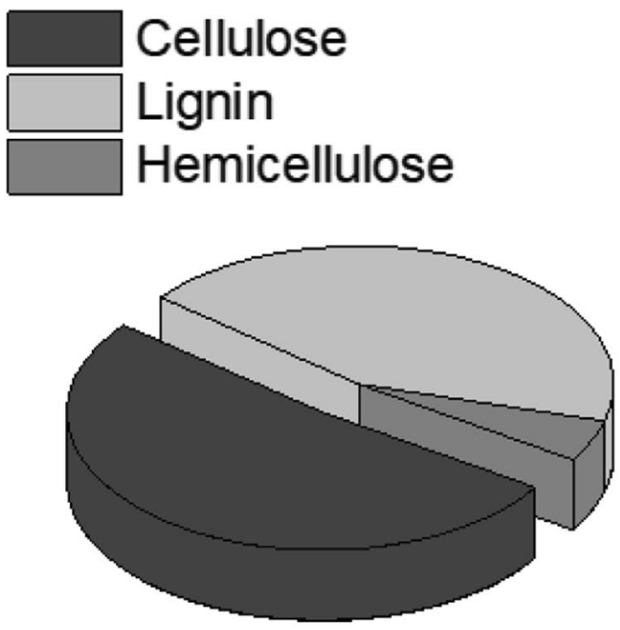

(a)

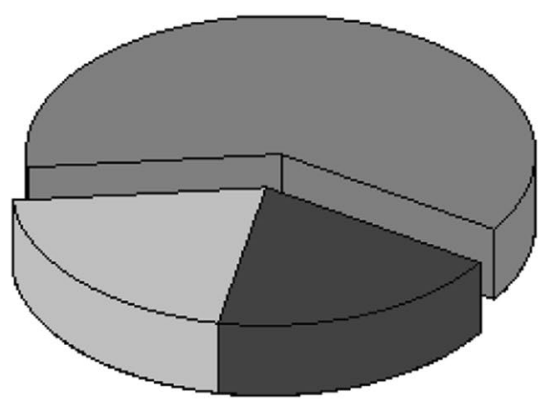

(b)

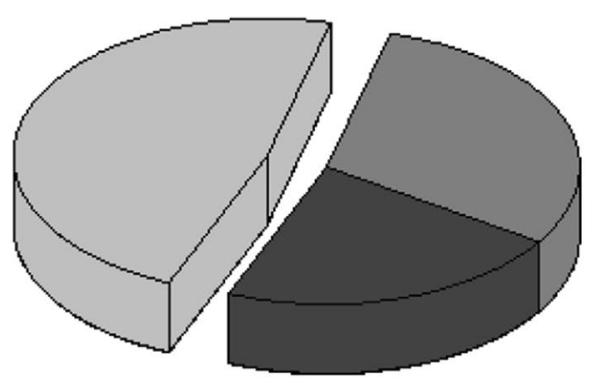

(c)

carbon yield). However, product selectivity (see Table 3) is not affected.

Even though $\mathrm{CO}_{2}$ is formed as main by-product in the gas-phase, the presented valorization method will certainly add on to the $\mathrm{CO}_{2}$ abatement in the atmosphere compared to common FA production methods like the hydrolysis of methyl formate. As $\mathrm{CO}_{2}$ contained in FA and $\mathrm{CO}_{2}$ by-product is trapped from the atmosphere while plant growing. In fact, the gaseous carbon dioxide can be separated and used for other biomass productions, such as large-scale micro algae production [40].

\section{Conclusion}

This study gives good arguments for the scientific and economic usefulness of the OxFA process for converting recovered biomass from agro-industry into valuable chemicals. It was possible to expand the biomass scope for the reaction significantly, by transforming many complex water-insoluble feedstocks, which are highly attractive considering other geographies and countries with similar agro-industrial sectors in Latin America, Asia, and Africa.
Seven fully characterized residual biomasses recovered from agro-industrial wastes were successfully valorized for the production of important commodities, for present and future applications, such as formic acid, acetic acid, and $\mathrm{CO}_{2}$ in high yields. The developed reaction works with an affordable POM catalyst (HPA-5), TSA as additive, and oxygen at relatively mild reaction conditions $\left(90^{\circ} \mathrm{C}, 20\right.$ bar $\mathrm{O}_{2}$, and $24 \mathrm{~h}$ ) in aqueous phase. Remarkably, coffee husk and cocoa husk residues showed quite promising results with high yields towards formic and acetic acid up to 64 and $57 \%$, respectively. With favorable selectivity towards FA formation (coffee husks: FA/AA selectivity [\%]: 43/22), being almost twice as high as for AA. Higher amounts of cellulose and hemicellulose contents in the biomass structure could be successfully correlated to higher yields towards FA and AA during the oxidative process (coffee husks $>$ cocoa husks $>$ palm rachis $\approx$ sugarcane bagasse), while substrates with higher lignin concentrations showed the lowest FA yields (e.g. Palm fiber and nut). This complete screening of several representative residual biomasses obtained from food providing agro-industry opens new interesting perspectives towards biomass valorization. This will promote the use of the "OxFA process" in new hydrogen production routes. 
However, there are still some technical drawbacks that must be solved, e.g., the efficient catalyst recirculation for reducing production costs. Moreover, the results also suggest a need for further investigations concerning the application of different types of polyoxometalate catalysts, for not only producing FA, but also high-purity cellulose that can be used for bioethanol production, for instance.

Supplementary Information The online version contains supplementary material available at https://doi.org/10.1007/s13399-021-01854-7.

Author contribution Sebastian Ponce: main idea, biomass characterization, complete data analysis, manuscript draft.

Stefanie Wesinger: oxidation reaction experiments.

Daniela Ona: biomass characterization (biomass treatment, lignocellulose content tests, imaging).

Daniela Almeida S.: biomass characterization (biomass treatment, lignocellulose content tests, CHNS contents), manuscript revision.

Jakob Albert: project director, data analysis, manuscript elaboration.

Funding Open Access funding enabled and organized by Projekt DEAL. This research has been supported by the "Collaboration Grant 2020 Program" at Universidad San Francisco de Quito USFQ.

Availability of data and materials Not applicable.

Code availability Not applicable.

\section{Declarations}

Ethics approval Not applicable.

Consent to participate All authors agree to participate in the study.

Consent for publication All authors agree on sending the manuscript for publication in Biomass Conversion and Biorefinery Journal.

Conflict of interest The authors declare no competing interests.

Open Access This article is licensed under a Creative Commons Attribution 4.0 International License, which permits use, sharing, adaptation, distribution and reproduction in any medium or format, as long as you give appropriate credit to the original author(s) and the source, provide a link to the Creative Commons licence, and indicate if changes were made. The images or other third party material in this article are included in the article's Creative Commons licence, unless indicated otherwise in a credit line to the material. If material is not included in the article's Creative Commons licence and your intended use is not permitted by statutory regulation or exceeds the permitted use, you will need to obtain permission directly from the copyright holder. To view a copy of this licence, visit http://creativecommons.org/licenses/by/4.0/.

\section{References}

1. Shafiee S, Topal E (2009) When will fossil fuel reserves be diminished? Energy Policy 37:181-189. https://doi.org/10.1016/j.enpol. 2008.08.016

2. Yamakawa CK, Qin F, Mussatto SI (2018) Advances and opportunities in biomass conversion technologies and biorefineries for the development of a bio-based economy. Biomass Bioenerg 119:54-60. https://doi.org/10.1016/j.biombioe.2018.09.007

3. Khan TA, Saud AS, Jamari SS et al (2019) Hydrothermal carbonization of lignocellulosic biomass for carbon rich material preparation: a review. Biomass Bioenerg 130:105384. https://doi.org/10. 1016/j.biombioe.2019.105384

4. Popp J, Lakner Z, Harangi-Rákos M, Fári M (2014) The effect of bioenergy expansion: Food, energy, and environment. Renew Sustain Energy Rev 32:559-578. https://doi.org/10.1016/j.rser. 2014.01.056

5. Gamborg C, Millar K, Shortall O, Sandøe P (2012) Bioenergy and land use: framing the ethical debate. J Agric Environ Ethics 25:909-925. https://doi.org/10.1007/s10806-011-9351-1

6. Reid WV, Ali MK, Field CB (2020) The future of bioenergy. Glob Chang Biol 26:274-286. https://doi.org/10.1111/gcb.14883

7. Belenky AS, Farazmand A, Vasin A (2019) The Management of large scale energy projects: opportunities and challenges. Int J Public Adm 42:1251-1255. https://doi.org/10.1080/01900692. 2019.1675929

8. Carriquiry MA, Du X, Timilsina GR (2011) Second generation biofuels: Economics and policies. Energy Policy 39:4222-4234. https://doi.org/10.1016/j.enpol.2011.04.036

9. Landis DA, Gratton C, Jackson RD et al (2018) Biomass and biofuel crop effects on biodiversity and ecosystem services in the North Central US. Biomass Bioenerg 114:18-29. https://doi.org/ 10.1016/j.biombioe.2017.02.003

10. Sadh PK, Duhan S, Duhan JS (2018) Agro-industrial wastes and their utilization using solid state fermentation: a review. Bioresour Bioprocess 5:1. https://doi.org/10.1186/s40643-017-0187-z

11. Margallo M, Ziegler-Rodriguez K, Vázquez-Rowe I et al (2019) Enhancing waste management strategies in Latin America under a holistic environmental assessment perspective: a review for policy support. Sci Total Environ 689:1255-1275. https://doi.org/10. 1016/j.scitotenv.2019.06.393

12. ESIN CONSULTORA SA Sa EC (2014) ATLAS Bioenergético de la República del Ecuador, MINISTERIO COORDINADOR DE PRODUCCION, Quito

13. Posso F, Siguencia J, Hydrogen RN-IJ, of, (2020) U (2020) Residual biomass-based hydrogen production: potential and possible uses in Ecuador. Elsevier 45:13717-13725. https://doi.org/10. 1016/j.ijhydene.2019.09.235

14. Vargas DC, Salazar S, Mora JR et al (2020) Experimental and theoretical study of the thermal decomposition of ethyl acetate during fast pyrolysis. Chem Eng Res Des 157:153-161. https:// doi.org/10.1016/j.cherd.2020.03.001

15. Salgado MAH, Tarelho LAC, Matos A (2020) Analysis of combined biochar and torrefied biomass fuel production as alternative for residual biomass valorization generated in small-scale palm oil mills. Waste Biomass Valor 11:343-356. https://doi.org/10.1007/ s12649-018-0467-7

16. Pérez-Arévalo JJ, Velázquez-Martí B (2018) Evaluation of pruning residues of Ficus benjamina as a primary biofuel material. Biomass Bioenerg 108:217-223. https://doi.org/10.1016/j.biomb ioe.2017.11.017

17. Streitwieser DA, Cabezas IC (2018) Preliminary study of biomethane production of organic waste based on their content of sugar, starch, lipid, protein and fibre. Chem Eng Trans 65:661-666

18. Almeida Streitwieser D (2017) Comparison of the anaerobic digestion at the mesophilic and thermophilic temperature regime of organic wastes from the agribusiness. Bioresour Technol 241:985-992. https://doi.org/10.1016/j.biortech.2017.06.006

19. Larrea FA, Salazar S, Andino C et al (2020) Comparison of bioethanol production of starches from different andean tubers. Chem Eng 80:259-264

20. Fukuzumi S, Kobayashi T, Suenobu T (2010) Unusually large tunneling effect on highly efficient generation of hydrogen and 
hydrogen isotopes in $\mathrm{pH}$-selective decomposition of formic acid catalyzed by a heterodinuclear iridium-ruthenium complex in water. J Am Chem Soc 132:1496-1497. https://doi.org/10.1021/ ja910349w

21. Hou Y, Nui M, Wu W (2020) Catalytic Oxidation of Biomass to Formic Acid Using O2 as an Oxidant. Ind Eng Chem Res 59(39):16899-16910. https://doi.org/10.1021/acs.iecr.0c01088

22. Albert J, Jess A, Kern C et al (2016) Formic acid-based FischerTropsch synthesis for green fuel production from wet waste biomass and renewable excess energy. ACS Sustain Chem Eng 4:5078-5086. https://doi.org/10.1021/acssuschemeng.6b01531

23. Albert J, Wölfel R, Bösmann A, Wasserscheid P (2012) Selective oxidation of complex, water-insoluble biomass to formic acid using additives as reaction accelerators. Energy Environ Sci 5:7956-7962. https://doi.org/10.1039/C2EE21428H

24. Reichert J, Brunner B, Jess A et al (2015) Biomass oxidation to formic acid in aqueous media using polyoxometalate catalystsboosting FA selectivity by in-situ extraction. Energy Environ Sci 8:2985-2990. https://doi.org/10.1039/C5EE01706H

25. Albert J, Lüders D, Bösmann A et al (2014) Spectroscopic and electrochemical characterization of heteropoly acids for their optimized application in selective biomass oxidation to formic acid. Green Chem 16:226-237. https://doi.org/10.1039/C3GC41320A

26. Albert J, Wasserscheid P (2015) Expanding the scope of biogenic substrates for the selective production of formic acid from waterinsoluble and wet waste biomass. Green Chem 17:5164-5171. https://doi.org/10.1039/C5GC01474C

27. Albert J (2017) Selective oxidation of lignocellulosic biomass to formic acid and high-grade cellulose using tailor-made polyoxometalate catalysts. Faraday Discuss 202:99-109. https://doi.org/ 10.1039/C7FD00047B

28. Voß D, Ponce S, Wesinger S, Etzold, BJM, Albert J (2019) Combining autoclave and LCWM reactor studies to shed light on the kinetics of glucose oxidation catalyzed by doped molybdenumbased heteropoly acids. RSC Adv 9:29347-29356. https://doi.org/ $10.1039 / \mathrm{c} 9 \mathrm{ra05544d}$

29. Preuster P, Albert J (2018) Biogenic formic acid as a green hydrogen carrier. Energy Technol 6:501-509. https://doi.org/10.1002/ ente. 201700572

30. Reichert J, Albert J (2017) Detailed kinetic investigations on the selective oxidation of biomass to formic acid (OxFA Process) using model substrates and real biomass. ACS Sustain Chem Eng 5:7383-7392. https://doi.org/10.1021/acssuschemeng.7b01723
31. Ponce S, Trabold M, Drochner A, Albert J, Etzold BJM (2019) Insights into the redox kinetics of vanadium substituted heteropoly acids through liquid core waveguide membrane microreactor studies. Chem Eng J 369:443-450. https://doi.org/10.1016/j.cej.2019. 03.103

32. Odyakov VF, Zhizhina EG (2008) A novel method of the synthesis of molybdovanadophosphoric heteropoly acid solutions. React Kinet Catal Lett 95:21-28. https://doi.org/10.1007/ s11144-008-5374-7

33. Latimer GW (2012) AOAC international. Off methods Anal AOAC Int 19th ed Gaithersburg, MD, USA AOAC Int

34. Thiex NJ, Anderson S, Gildemeister B (2003) Crude fat, diethyl ether extraction, in feed, cereal grain, and forage (Randall/Soxtec/ submersion method): collaborative study. J AOAC Int 86:888-898

35. Mariotti F, Tomé D, Mirand PP (2008) Converting nitrogen into protein-beyond 6.25 and Jones' factors. Crit Rev Food Sci Nutr 48:177-184. https://doi.org/10.1080/10408390701279749

36. Kulić GJ, Radojičić VB (2011) Analysis of cellulose content in stalks and leaves of large leaf tobacco. J Agric Sci Belgrade 56:207-215

37. Voß D, Kahl M, Albert J (2020) Continuous production of formic acid from biomass in a three-phase liquid-liquid-gas reaction process. ACS Sustain Chem Eng. https://doi.org/10.1021/acssuschem eng.0c02426

38. Klinghoffer NB, Castaldi MJ, Nzihou A (2015) Influence of char composition and inorganics on catalytic activity of char from biomass gasification. Fuel 157:37-47. https://doi.org/10.1016/j.fuel. 2015.04.036

39. Cheng F, Li X (2018) Preparation and application of biocharbased catalysts for biofuel production. Catalysts 8(9):346. https:// doi.org/10.3390/catal8090346

40. Elmoraghy M, Farag IH (2012) Bio-jet fuel from microalgae: reducing water and energy requirements for algae growth. Int $\mathbf{J}$ Eng Sci 1:22-30

Publisher's note Springer Nature remains neutral with regard to jurisdictional claims in published maps and institutional affiliations. 